\title{
Faktor-Faktor Yang Mempengaruhi Kesejahteraan Masyarakat di Provinsi Riau
}

\author{
Wiwin Indrayanti \\ Universitas Diponegoro, wiwinindrayanti@students.undip.ac.id
}

\begin{abstract}
ABSTRAK
Tingkat kesejahteraan yang memiliki tren berfluktuatif dengan kecenderungan menurun, akan berdampak pada berkurangnya kemampuan masyarakat dalam memenuhi kebutuhannya, sehingga akan mempengaruhi kesejahteraannya. Penelitian ini bertujuan untuk menganalisis faktor-faktor yang mempengaruhi kesejaheteraan masyarakat di Provinsi Riau. Variabel digunakan dalam penelitian ini meliputi tingkat kemiskinan, tingkat pengangguran terbuka (TPT), pengeluaran per kapita, dan pertumbuhan ekonomi. Metode yang digunakan regresi data panel dengan menggunakan sumber data sekunder yang diperoleh dari Badan Pusat Statistik (BPS) pada tahun 2008-2017. Analisis data dilakukan menggunakan pendekatan deskriptif kuantitatif. Teknik sampling yang digunakan adalah sampling jenuh dengan data 11 kabupaten/kota di Provinsi Riau. Hasil penelitian menunjukan bahwa tingkat kemiskinan berpengaruh negatif dan pengeluaran per kapita berpengaruh positif terhadap kesejahteraan masyarakat, sedangkan tingkat pengangguran dan pertumbuhan tidak signifikan terhadap kesejahteraan masyarakat. Analisis ini diharapkan dapat menyajikan informasi mengenai kondisi kesejahteraan di Provinsi Riau sebagai bahan evaluasi pembangunan. Pembaharuan kebijakan pemerintah pada sektor ekonomi perlu dilakukan untuk mencegah atau mengurangi kemiskinan dan pengangguran, serta membuat program pengembangan menuju masyarakat yang sejahtera.

Kata Kunci : kesejahteraan masyarakat, kemiskinan, TPT, pengeluaran per kapita, PDRB
\end{abstract}

\begin{abstract}
The level of welfare that has a fluctuating trend with a downward trend, will have an impact on the reduced ability of the community to meet their needs, so that will affect their welfare. This study aims to analyze the factors that affect the welfare of the people in Riau Province. The variables used in this study include the level of poverty, the level of open unemployment (TPT), per capita expenditure, and economic growth. The method used panel data regression that uses secondary data sources obtained from the Central Statistics Agency (BPS) in 2008-2017. Data analysis was performed using a quantitative descriptive approach. The sampling technique used is sampling saturated with data in 11 districts and cities in Riau Province. The results showed that the poverty rate has a negative effect and per capita expenditure has a positive effect on community welfare, while the unemployment and growth rates do not significantly affect on community welfare.This analysis is expected to provide information on welfare conditions in Riau Province as material for development evaluation. Reform of government policies in the economic sector needs to be done to prevent or reduce poverty and unemployment, and create development programs towards a prosperous society.
\end{abstract}

Keywords: community welfare, poverty, TPT, per capita expenditure, GRDP

Naskah diterima: 29-08-2020, direvisi: 14-07-2020, diterbitkan: 01-09-2020

ISSN: 2355-0295, e-ISSN: 2549-8932

http://ejournal.bsi.ac.id/ejurnal/index.php/ecodemica 


\section{PENDAHULUAN}

Pembangunan ekonomi pada hakikatnya bertujuan untuk meningkatkan kesejahteraan masyarakat, dengan melakukan perubahan pada aspek politik, ekonomi, dan sosial budaya. Proses pembangunan dapat dilakukan dengan cara pengembangkan perekonomian dan mengatasi berbagai permasalahan pembangunan. Untuk itu, keberhasilan pembangunan dapat dicapai dengan membuat perencanan yang dapat mengatasi permasalahan dan meningkatkan perekonomian, sehingga akan meningkatkan kesejahteraan masyarakat (Kartasasmita, 1996).

Pengangguran dan kemiskinan merupakan penghambat peningkatan kesejahteraan organisasi perubahan dunia (ILO) pada tahun 1997, dalam mengatasi ini dengan membuat program yang dapat menciptakan lapangan kerja, sehingga masyarakat dapat memenuhi kebutuhan pokoknya.

Pertumbuhan ekonomi merupakan indikator keberhasilan pembangunan. Untuk itu, setiap daerah berupaya membuat kebijakan meningkatkan pertumbuhan ekonominya. Pertumbuhan ekonomi dapat di ukur dengan besarnya kenaikan Produk Domestik Regional Bruto (PDRB). Pertumbuhan ekonomi dapat tercapai dengan adanya peningkatan kapasitas produksi pada kurun waktu tertentu (Todaro \& C. Smith, 2013). Hal ini dapat terjadi karena dengan adanya peningkatan PDRB, akan menambah pendapatan dan pengeluaran masyarakat, sehingga berdampak pada peningkatan distribusi pendapatan.

Badan program pembangunan PBB (UNDP) menggunakan indeks pembangunan manusia (IPM), sebagai indikator kesuksesan pemabngunan dan kesejahteraan suatu negara. IPM digunakan untuk mengukur capaian pemabngunan manusia yang berbasis pada sejumlah komponen dasar kualitas hidup, yang meliputi dimensi umur panjang dan sehat dengan indikator harapan hidup saat lahir, dimensi pengetahuan dengan indikator harapan lama sekolah dan rata-rata lama sekolah, serta standar hidup layak dengan indikator pengeluaran per kapita (BPS, 2018). masyarakat. Adapun strategi yang dibuat

Provinsi Riau melakukan pemabngunan di berbagai bidang untuk meningkatkan taraf hidup masyarakatnya. Kebijakan pembangunan yang dilakukan, telah berhasil meningkatkan indeks pembangunan manusia (IPM) pada tahun 2008-2017.

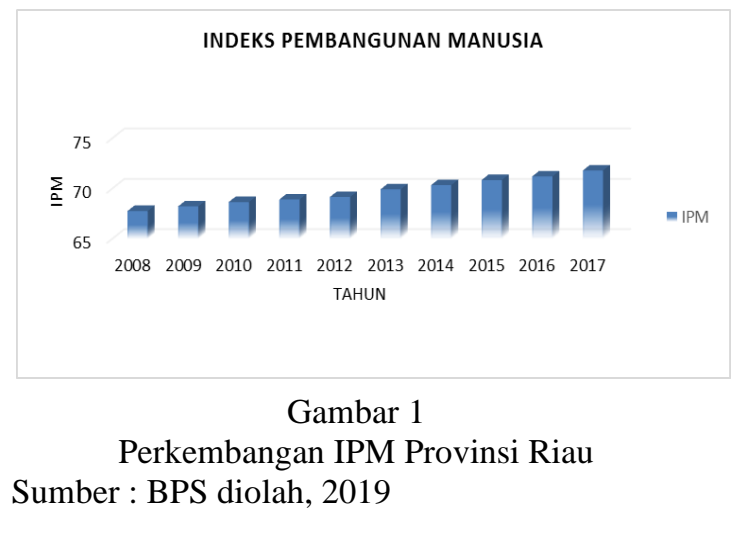

Riau pada 2017 dengan memiliki IPM sebesar 71,79 berada pada peringkat 6 dari 34 provinsi di Indonesia. Kondisi ini, berdasarkan skala internasional karena IPM berada antara 66-80 masuk dalam kategori kelompok menengah atas.

Di sisi lain dari peningkatan Indeks Pembangunan Manusia, Provinsi Riau juga memiliki permasalahan perekonomian seperti kemiskinan dan pengangguran. Jumlah penduduk miskin sebanyak 514,62 ribu jiwa dan pengangguran yang semakin meningkat dengan laju 6,22 persen (BPS, 2018). Kondisi kemiskinan provinsi Riau dapat di lihat pada gambar berikut ini :

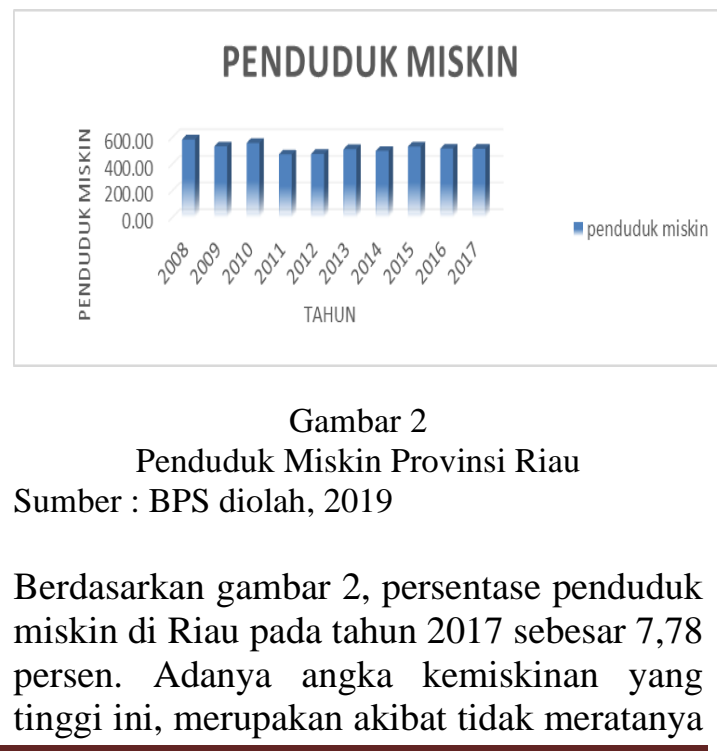

ISSN: 2355-0295, e-ISSN: 2528-2255

354 
pembangunan antar wilayah, sehingga pemerintahnya melakukan upaya untuk mengentaskan kemiskinan.

Menurut Survei Sosial Ekonomi Nasional yang dilakukan oleh pemerintah, jumlah penduduk miskin masih tergolong tinggi meskipun angka kemiskinan mengalami penurunan dari tahun ke tahun. Penurunan tingkat kemiskinan dari tahun 2008-2017 terbesar terdapat pada tahun 2011 dengan penurunan sebesar 85,55 ribu jiwa.

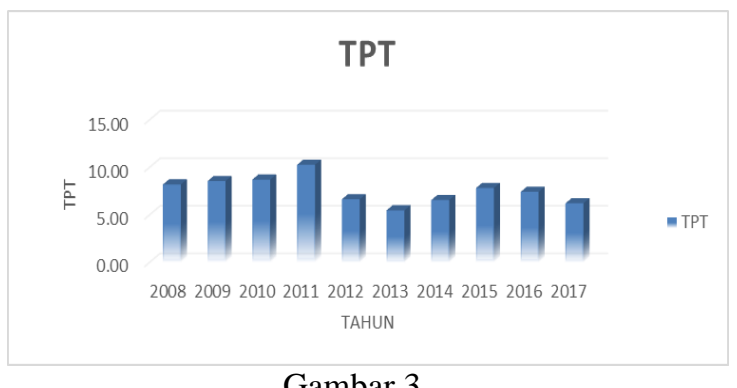

TPT Provinsi Riau Tahun 2008-2017

Sumber : BPS diolah,2019

Pada gambar 3, pengangguran pada 20082017 berfluktuatif dengan tren yang menurun.. Masalah pengangguran selalu berkaitan dengan masalah kependudukan. Pada tahun 2011 angka pengangguran meningkat tinggi sebesar 10,27 persen karena pada tahun yang sama pertumbuhan penduduk semakin meningkat yang menyebabkan penyediaan kesempatan kerja tidak mencukupi sehingga menimbulkan pengangguran dan setengah menganggur.

Pemerintah provinsi Riau berupaya menekan angka pengangguran dengan membuka lapangan pekerjaan, namun lapangan kerja yang tersedia tidak berbanding lurus dengan banyaknya penduduk yang membutuhkan pekerjaan. Kondisi ini, menjadi semakin berat dengan adanya imigran yang datang ke Riau, sehingga pemerintahnya hanya dapat menurunkan pengangguran pada 2011-2013 sebesar 4.79 persen.

Pendapatan perkapita masyarakat di provinsi Riau tergolong tinggi. Dari gambar 4 terlihat bahwa pengeluran perkapita masyarakat provinsi Riau dari tahun 2008-2017 mengalami peningkatan yang signifikan.
PENGELUARAN PERKAPITA

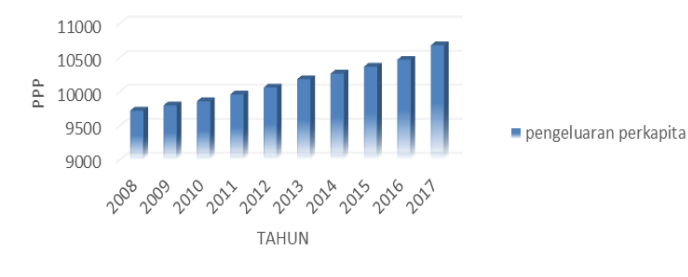

Gambar 4

Pengeluaran Perkapita Provinsi Riau Tahun 2008-2017

Sumber : BPS diolah,2019

Peningkatan pendapatan perkapita tersebut berimbas pada pergeseran pola konsumsi yang menyebabkan pengeluran perkapita juga meningkat. Menurut Survei Sosial Ekonomi Nasional menunjukan bahwa selama 10 tahun terakhir telah terjadi perubahan orientasi konsumsi rumah tangga Riau. Peningkatan pengeluraan terjadi karena adanya peningkatan pendapatan masyarakat. Adanya peningkatan pengeluaran perkapita, menunjukan terjadinya kenaikan kesejahteraan masyarakatnya.

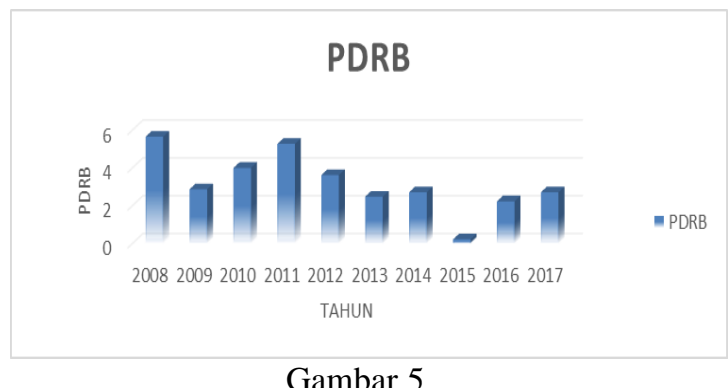

PDRB Provinsi Riau Tahun 20082017

Sumber : BPS diolah, 2019

Pada 2017 pertumbuhan ekonomi Riau melampaui Indonesia. Pertumbuhan ekonomi Provinsi Riau tercatat dengan nilai sebesar Rp. 705,68 atau 5,10 persen. Namun, pada tahun 2015, pertumbuhannya mengalami tren yang menurun.

Penelitian ini berbeda dari penelitian sebelumnya dalam beberapa hal. Umumnya, studi empiris sebelumnya berfokus pada hubungan antara tingkat kemiskinan, tingkat pengangguran, pendapatan perkapita dan pertumbuhan ekonomi yang dipandang dapat mempengaruhi kesejahteraan (Chalid 
\& Yusuf, 2014). Modifikasi dari panelitian ini adalah mempertimbangkan bagaimana pengeluaran perkapita dapat mempengaruhi kesejahteraan. Mengingat bahwa kesejahteraan juga dapat tercermin dari pendapatan yang dibelanjakan atau dikeluarkan untuk memenuhi kebutuhan (Mu'arifah, 2016). Penelitian yang dilakukan oleh Amare et al., (2012); Maluccio et al., (2000) menunjukan bahwa pengeluaran perkapita mampu mempengaruhi kesejaheraan, berbeda dengan pendapat Badrudin \& Kuncorojati, (2017) yang menemukan bahwa kesejahteraan masyarakat tidak ditentukan oleh besarnya pengeluaran perkapita. Research gap dalam penelitian ini muncul karena adanya perbedaan hasil temuan diantara penelitian diatas.

Terdapat beberapa indikator yang dapat mempengaruhi kesejahteraan masyarakat di Riau. Dengan diketahuinya indikator yang mempengaruhi kesejahteraan masyarakat, dapat di buat program pengembangan menuju masyarakat sejahtera. Untuk itu, perlu dilakukan penelitian faktor-faktor yang mempengaruhi kesejahteraan masyarakat di Provinsi Riau.

\section{KAJIAN LITERATUR}

Kesejahteraan sosial merupakan suatu kondisi atau keadaan sejahtera, baik fisik, mental maupun sosial, dan tidak hanya perbaikan terhadap penyakit sosial tertentu saja (Chalid \& Yusuf, 2014). BPS mengukur kesejahteran rakyat melalui delapan bidang, yaitu kependudukan, kesehatan dan gizi, pendidikan, ketenagakerjaan, taraf dan pola konsumsi, perumahan dan lingkungan, kemiskinan, dan sosial lainnya (BPK, 2008). Kemiskinan adalah suatu kondisi ketidakmampuan secara ekonomi untuk memenuhi standar hidup rata-rata masyarakat di suatu daerah. Masyarakat dapat dikatakan miskin apabila memiliki pendapatan jauh lebih rendah dari rataratanya sehingga tidak memiliki kesempatan untuk mensejahterakan dirinya (Suryawati, 2003). Kesejahteraan yang dipengaruhi oleh kemiskinan sesuai dengan penelitian AlNasser \& Hallaq (2019); Ariza (2016);
Chalid \& Yusuf (2014); Churchill (2020); Darsana (2016).

Pengangguran adalah suatu keadaan di mana seseorang yang tergolong dalam angkatan kerja ingin mendapatkan pekerjaan tetapi belum dapat memperolehnya (Sukirno, 2013). Pengangguran merupakan masalah makroekonomi yang dapat mempengaruhi manusia secara langsung dan merupakan yang paling berat. Bagi kebanyakan orang, kehilangan pekerjaan berarti penurunan standar kehidupan dan tekanan psikologis. Jadi tidaklah mengejutkan jika pengangguran menjadi topik yang sering dibicarakan dalam perdebatan politik dan para politisi sering mengklaim bahwa kebijakan yang mereka tawarkan akan membantu menciptakan lapangan kerja (Mankiw, 2010). Penelitian yang dilakukan oleh Chalid \& Yusuf (2014); Ojima (2019) menunjukan bahwa tingkat pengangguran merupakan salah satu faktor yang berpotensi mempengaruhi kesejahteraan masyarakat.

Menurut BPS, perubahan pendapatan seseorang akan berpengaruh pada pergeseran pola pengeluaran. Semakin tinggi pendapatan, semakin tinggi pengeluaran bukan makanan. Dengan demikian, pola pengeluaran dapat dipakai sebagai salah satu alat untuk mengukur tingkat kesejahteraan penduduk, dimana perubahan komposisinya digunakan sebagai petunjuk perubahan tingkat kesejahteraan. Pernyataan tersebut cukup mendukung penelitian sebelumnya yang pernah dilakukan oleh Arifin et al., (2020); Gomanee et al., (2003); Paul et al., (2014) bahwa pengeluaran per kapita mempunyai hubungan positif yang berarti bahwa semakin tinggi pengeluaran masyarakat, maka semakin tinggi tingkat kesejahteraan.

Pertumbuhan ekonomi menjadi salah satu indikator keberhasilan pembangunan dalam suatu perekonomian. Adanya pertumbuhan ekonomi dapat mengupayakan peningkatan kapasitas

produksi untuk meningkatkan output, yang diukur menggunakan Produk Domestik Bruto (PDB) maupun Produk Domestik Regional Bruto (PDRB) dalam suatu wilayah (Adisasmita, 2013). Penelitian yang dilakukan oleh Ariza (2016); Chalid \& 
Yusuf (2014); Nurarif (2013); Reyes \& Useche (2019) menemukan bahwa pertumbuhan ekonomi yang ditunjukan pada nilai PDRB cukup mampu mempengaruhi kesejahteraan masyarakat.

Berdasarkan tinjuan pustaka dan penelitian terdahulu dapat dibuat hipotesis. Adapun hipotesisnya adalah :

$\mathrm{H}_{1}$ :Tingkat kemiskinan berpengaruh negatif terhadap kesejahteraan masyarakat di Provinsi Riau.

$\mathrm{H}_{2}$ : Tingkat pengangguran berpengaruh negatif terhadap kesejahteraan masyarakat di Provinsi Riau.

$\mathrm{H}_{3}$ : Pengeluaran perkapita berpengaruh positif terhadap kesejahteraan masyarakat di Provinsi Riau.

$\mathrm{H}_{4}$ : Pertumbuhan ekonomi berpengaruh positif terhadap kesejahteraan masyarakat di Provinsi Riau.

Kerangka pemikiran dapat digambar sebagai berikut:

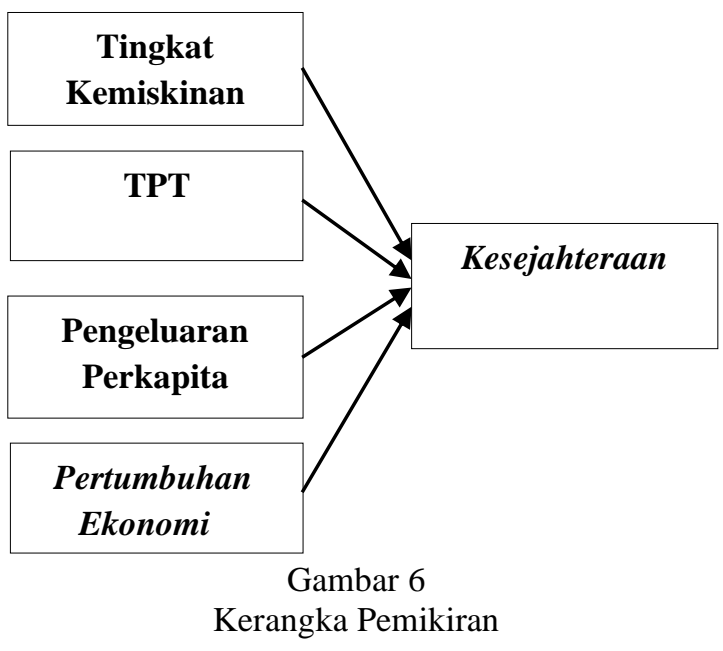

\section{METODE PENELITIAN}

Penelitian ini, menggunakan metode regresi data panel dengan data sekunder pada tahun 2008-2017 di kabupaten dan kota provinsi Riau, yang diperoleh dari Badan Pusat Statistik. Data Indeks Pembangunan Manusia (IPM) Kabupaten dan Kota di Provinsi Riau berjumlah 12, akan tetapi hanya 11 kabupaten dankota yang dijadikan objek penelitian karena ada salah satu kabupaten ada yang berdiri pada tahun 2010, sehingga datanya tidak valid yaitu kabupaten Kepulauan Meranti. Sampel penelitian diambil dengan menggunakan sampling jenuh. Sampling jenuh adalah teknik penentuan sampel bila semua anggota populasi digunakan sebagai sampel (Sugiyono, 2017).

\section{Estimasi Model Regresi Data Panel}

Regresi data panel memiliki tiga model. Adapun ketiga modelnya dalah :

\section{a. Common Effect (CE)}

Model ini menggabungkan data cross section dan data time series, kemudian dengan menggunakan metode OLS terhadap data panel tersebut. pendekatan yang digunakan dapat melihat perbedaan antar waktu karena interseptnya maupun slope sama. Model ini tidak memperhatikan adanya perbedaan karakteristik dalam cross section maupun time series.

\section{b. Fixed Effect (FE)}

Dalam model ini memiliki intercept yang mungkin berubah-ubah untuk setiap individu dan waktu, dimana setiap unit cross section bersifat tetap secara time series.

\section{c. Random Effect (RE)}

Model ini mumpunyai kesamaan dengan model sebelumnya yaitu fixed effects, dimana dimasukan juga dimensi individu dan waktu namun pembeda model ini dari fixed effects adalah dalam mengestimasi dimasukan juga error term karena dalam mengansumsikan error term berhubungan dengan dimensi individu maupun waktu.

\section{Pemilihan Model Regresi Data Panel}

Dari ketiga pendekatan yang telah diestimasi akan dipilih pendekatan mana yang paling tepat dengan tujuan penelitian. Ada tahapan uji (test) yang dapat dijadikan alat dalam memilih model regresi data panel (CE, FE atau RE) berdasarkan karakteristik data yang dimiliki, yaitu: F Test (Chow Test) dan Hausman Test

\section{a. Chow Test}

Uji chow ini bertujuan untuk menentukan bagaimana model digunakan apakah menggunakan common effect atau fixed effects, dengan hipotesis sebagai berikut:

$\mathrm{H}_{0}$ : Model Common Effect $(C E)$ $\mathrm{H}_{1}$ : Model Fixed Effect $(F E)$ 
Dalam menolak maupun menerima hipotesis di atas maka dilakukan perbandingan antara perhitungan F-tabel dan F-statistik, apabila F-statistik lebih besar dari F-tabel atau (prob $>$ f) $<\alpha$ maka H0 ditolak yang berati model yang paling cocok untuk digunakan merupakan model fixed effects, dan jika Fstatistik lebih kecil atau (prob $>$ f) $>\alpha$ maka model yang paling cocok untuk digunakan ialah model common effect.

F-statistik $>$ F-tabel $=\mathrm{H}_{0}$ ditolak

F-statistik $<$ F-tabel $=\mathrm{H}_{0}$ diterima

\section{b. Hausman Test}

Uji Hausman merupakan uji lanjutan dalam memilih model regresi data panel. Uji ini dilakukan ketika hasil yang ditunjukan oleh Uji Chow, model fixed Effects lebih bagus, dalam Uji hausman akan di pilih lagi manakah yang lebih cocok digunakan antara fixed effect dan random effect, uji hausman menggunakan hipotesis sebagai berikut:

$$
\mathrm{H}_{0} \text { : Model Random Effect (RE) }
$$$$
\mathrm{H}_{1} \text { : Model Fixed Effect (FE) }
$$

Dalam menolak maupun menerima hipotesis di atas uji hausman ini mengikuti distribusi statistik chi square dengan degree of freedom sebanyak $\mathrm{k}$, dimana $\mathrm{k}$ adalah jumlah variabel independen. Jika nilai probailitas chi square maka kurang dari nilai kritis maka model yang digunakan adalah fixed effect, sebaliknya jika penolakan $\mathrm{H}_{\mathrm{o}}$ tidak signifikan maka yang digunakan adalah random effect (Gujarati et al., 2013).

\section{c. Lagrange Multiplier Test}

LM test dilakukan dengan tujuan untuk menentukan model terbaik dalam regresi data panel, apakah model random effect lebih atau common effect.

LM test harus dilakukan jika model berada dalam dua kondisi, yaitu:

1. Uji Chow menunjukkan bahwa model terbaik adalah common effect.

2. Tes Hausman menunjukkan bahwa model terbaik adalah random effect.

Jika diperoleh nilai $\mathrm{p}$ value kurang dari 0,05 , maka model terbaik yang dipilih adalah random effect, sedangkan jika $\mathrm{p}$ value lebih dari 0,05 maka model common effect yang harus digunakan.

$\mathrm{H}_{0}$ : Model Common Effect $(C E)(\mathrm{p}>0,05)$

$\mathrm{H}_{1}$ : Model Random Effect $(R E)(\mathrm{p}<0,05)$

\section{Uji Hipotesis}

Pengujian hipotesis dilakukan untuk memperoleh koefisien determinasi (adjusted $R^{2}$ ), uji parsial dan uji simultan. Nilai Adjusted $\mathrm{R}^{2}$ berkisar antara $0<$ Adjusted $\mathrm{R}^{2}<1$. Semakin besar nilai Adjusted $\mathrm{R}^{2}$ ( mendekati 100 persen) semakin baik model regresi tersebut. Nilai adjusted $\mathrm{R}^{2}$ sebesar 0 berarti varians dari variabel dependen tidak dapat diterangkan sama sekali oleh variabel independennya dan sebaliknya.

Uji parsial dapat dilakukan dengan menggunakan nilai probabilitas kesalahan estimasi ( $\rho$-value). Nilai probabilitas kesalahan estimasi ( $\rho$-value) dapat ditentukan melalui nilai standarisasi $\mathrm{Z}$ dengan formulasi sebagai berikut :

Nilai $\mathrm{t}$ atau $\mathrm{Z}=\mathrm{b} 1-\beta_{1}$

1. Jika probabilitas $(p$-value $)>$ nilai kritis, maka tidak signifikan

2. Jika probabilitas $(p$-value $)<$ nilai kritis, maka signifikan

Uji simultan dilakukan untuk mengetahui apakah semua variabel independen secara bersama - sama (simultan) berpengaruh terhadap variabel dependen. Bila probabilitas $(\mathrm{p}-$ value $)>$ nilai kritis, maka tidak signifikan. Bila probabilitas $(\mathrm{p}-$ value $)<$ nilai kritis, maka signifikan. Jika variasi nilai variabel dependen dapat dijelaskan oleh semua variabel independen dalam model regresi, maka dapat disimpulkan bahwa secara bersama - sama semua variabel independen di dalam model regresi berpengaruh terhadap variabel dependen. 


\section{PEMBAHASAN}

Dalam analisis data panel terdapat tiga pendekatan yang digunakan, yaitu common effect, fixed effect dan random effect. Setelah dilakukan pengujian dengan metode tertimbang (cross section weight), maka hasil yang diperoleh, sebagai berikut:

Tabel 1.

Hasil Estimasi

\begin{tabular}{|c|c|c|c|}
\hline \multirow{2}{*}{ Variabel } & \multicolumn{3}{|c|}{ Coefficient } \\
\cline { 2 - 4 } & CEM & FEM & REM \\
\hline TK & -0.016424 & -0.016424 & -0.01669 \\
\hline TPT & 0.243536 & 0.243536 & 0.028732 \\
\hline PPP & 0.002476 & 0.002476 & 0.002801 \\
\hline PE & -0.137818 & -0.137818 & -0.068318 \\
\hline C & 4.262 .250 & 4.262 .250 & 4.055 .685 \\
\hline $\begin{array}{c}\text { Prob } \\
\text { (F-statistic) }\end{array}$ & 0.000000 & 0.000000 & 0.000000 \\
\hline
\end{tabular}

Sumber : Hasil olahan data penelitian

\section{a. Uji Chow}

Pertama data panel diesmitasi menggunakan efek spesifikasi fixed. Uji yang dilakukan yaitu uji Chow. Uji ini bertujuan untuk mengetahui apakah sebaiknya model menggunakan fixed effect atau common effect $(C E)$.

$\mathrm{H} 0$ : common effect $(C E)$

$\mathrm{H} 1$ : Fixed Effect (FE)

Untuk menentukan pilihan antara $C E$ dan $F E$, maka dapat dilihat output FE. Apabila $\mathrm{P}$ value (Prob>f) < alpha 0,05 maka H1 diterima. Sehingga pilihan terbaik menggunakan fixed effect.

Berdasarkan hasil tersebut karena $\mathrm{P}$ value (Prob>F) sebesar 0.0000 sehingga H1 diterima. Maka model fixed effect adalah model yang sebaiknya digunakan.

\section{b. Hausmann Test}

Uji ini bertujuan untuk mengetahui apakah model random effect lebih baik digunakan dari fixed effect.

$H O$ :Random Effect (RE)

$H 1$ : Fixed Effect $(F E)$

Apabila hasil probabilitas $P$ value $($ Prob $>$ chi2 $)<$ alpha 0,05 maka HI diterima.

Berdasarkan hasil tersebut diperoleh $\mathrm{p}$ value $\left(\right.$ Prob $\left.>\mathrm{chi}^{2}\right)$ alpha 0,05 sebesar 0.0000 sehingga $\mathrm{H}_{1}$ diterima atau pilihan terbaik adalah fixed effect daripada random effect.

\section{Uji Statistik \\ Uji Determinasi (Adjusted $\mathbf{R}^{2}$ )}

Uji Koefisien Determinasi ( $R$ square) bertujuan untuk mengetahui seberapa jauh variasi veriabel independen dapat menerangkan dengan baik variasi veriabel dependen. Berdasarkan hasil regresi diperoleh koefisien adjusted $R$ square sebagai berkut:

Tabel 2

Hasil Uji Adjusted $R^{2}$

\begin{tabular}{|l|l|l|l|}
\hline Observasi & Adjusted $R^{2}$ & Chi Square & $P$ Value \\
\hline
\end{tabular}

Sumber : Hasil olahan data penelitian

Koefisien determinasi atau goodness of fit diperoleh angka adjusted square sebesar 0.894630 . Hal ini berarti bahwa kontribusi seluruh variabel bebas dalam menjelaskan variabel terikat sebesar 89,4 persen. Selisihnya sebesar 10,6 persen dijelaskan oleh variabel lain di luar model.

\section{Uji Parsial (Uji t-Statistik)}

Hasil analisis uji parsial menunjukkan bahwa semua variabel independen berpengaruh signifikan terhadap variabel dependen. Berikut tabel ringkasan uji parsial variabel independen terhadap variabel dependen:

Tabel 3

Ringkasan Hasil Uji Parsial

\begin{tabular}{|r|c|c|c|c|}
\hline V & T & Kritis & Prob & Ket \\
\hline TK & -0.016424 & 0.05 & 0.04630 & Signif \\
\hline TPT & 0.243536 & 0.05 & 0.0000 & No \\
\hline PPP & 0.002476 & 0.05 & 0.0000 & Signif \\
\hline PE & -0.137818 & 0.05 & 0.0019 & No \\
\hline
\end{tabular}

Hasil olahan data penelitian

\section{Uji Simultan (Uji F-Statistik)}

Berdasarkan hasil analisis diperoleh probabilitas F sebesar 0.0000 . Berarti pada taraf signifikansi 5 persen, probabilitas $\mathrm{F}$ lebih kecil dari nilai kritis maka uji $\mathrm{F}$ adalah signifikan. Oleh karena itu, dapat disimpulkan bahwa seluruh variabel secara 
bersama-sama berpengaruh terhadap variabel terikat. Variabel tingkat kemiskinan, tingkat Pengangguran, pengeluaran per kapita, pertumbuhan ekonomi secara bersama -sama berpengaruh signifikan terhadap kesejahteraan.

\section{Uji Hipotesis}

Berdasarkan hasil uji hipotesis, dapat diperoleh analisis faktor-faktor yang mempengaruhi kesejahteraan sebagai berikut

\section{a. Hipotesis 1}

Berdasarkan hasil perhitungan, tingkat kemiskinan memiliki probabilitas sebesar 0.04630. Dalam taraf signifikansi 5 persen maka variabel tingkat kemiskinan secara individu signifikan dalam mempengaruhi kesejahteraan. Nilai koefisien regresi sebesar -0.016424 menunjukkan arah negatif artinya tingkat kemiskinan berpengaruh negatif dan signifikan terhadap kesejahteraan.

Jumlah kemiskinan yang semakin berkurang akan menciptakan kemakmuran hidup masyarakat. Penurunan jumlah kemiskinan disebabkan karena sebagian besar masyarakat riau mulai membangun usaha sehingga mereka memperoleh pendapatan sendiri. Pendapatan dalam hal ini merupakan faktor yang dominan dalam peningkatan kesejahteraan masyarakat riau. Hasil penelitian ini cukup mendukung penelitian yang dilakukan oleh Al-Nasser \& Hallaq (2019); Ariza (2016); Chalid \& Yusuf (2014); Churchill (2020); Darsana (2016) yang berpendapat bahwa penurunan angka kemiskinan signifikan dengan peningkatan kemakmuran.

\section{b. Hipotesis 2}

Berdasarkan tabel 3 hasil tingkat pengangguran memiliki probabilitas sebesar 0.0000. Dalam taraf signifikansi 5 persen maka variabel tingkat pengangguran secara individu tidak signifikan dalam mempengaruhi kesejahteraan. Nilai koefisien regresi sebesar 0.243536 menunjukkan arah positif yang berarti bahwa tingkat pengangguran tidak mampu mempengaruhi kesejahteraan masyarakat.

Jumlah pengangguran yang semakin meningkat bukan berarti terjadi penurunan kesejahteraan. Sebagian besar usaha yang dijalankan masyarakat Riau bergerak dibidang pertanian atau perkebunan. Peningkatan jumlah pengangguran dikarenakan sebagian pengusaha yang bergerak dibidang tersebut dianggap tidak bekerja atau menganggur. Hal ini dapat dilihat pada data BPS tahun 2016 tercatat peningkatan angka pengangguran bersamaan dengan peningkatan kesejahteraan. Hubungan positif tingkat pengangguran dan kesejahteraan senada dengan pendapat Sholihah \& Kustanto (2017); Suganda (2012).

c. Hipotesis 3

Berdasarkan tabel 3 hasil pengeluaran perkapita memiliki probabilitas sebesar 0.0000. Dalam taraf signifikansi 5 persen maka variabel pengeluaran per kapita secara individu signifikan dalam mempengaruhi kesejahteraan. Nilai koefisien regresi sebesar 0.002476 menunjukkan tanda positif artinya tingkat pengangguran berpengaruh positif dan signifikan terhadap kesejahteraan.

Semakin banyak pengeluaran yang di keluarkan untuk konsumsi kebutuhan makanan dan non makanan oleh rumah tangga menunjukan adanya peningkatan pendapat yang diperoleh rumahtangga atau masyarakat provinsi Riau. Masyarakat yang dapat memenuhi kebutuhannya mencerminkan pencapaian kesejahteraan. Hasil penelitian ini didukung oleh Amare et al., (2012); Maluccio et al., (2000); Arifin et al., (2020); Gomanee et al., (2003); Paul et al., (2014) yang menyatakan bahwa pengeluaran perkapita mampu mempengaruhi kesejahteraan. 
d. Hipotesis 4

Berdasarkan hasil uji hipotesis menunjukan bahwa pertumbuhan ekonomi memiliki probabilitas sebesar 0.0019. Dalam taraf signifikansi 5 persen maka variabel pertumbuhan ekonomi dinilai tidak signifikan dalam mempengaruhi kesejahteraan, yang dikonfirmasi dengan nilai koefisien sebesar -0.137818 menunjukkan tanda negatif artinya pertumbuhan ekonomi berpengaruh negatif dan tidak signifikan terhadap kesejahteraan.

Berdasarkan data yang diperoleh, terlihat bahwa angka pertumbuhan ekonomi cenderung menurun tetapi mampu meningkatkan kesejaheraan masyarakat. Hal ini dapat terjadi karena pertumbuhan ekonomi di Provinsi Riau mengalami fluktuatif. Pertumbuhan positif dialami oleh sektor pertanian, manufacturing dan perdagangan. Tetapi pertumbuhan negatif tetap terjadi pada sektor pertambangan dan penggalian, yang secara signifikan mempengaruhi kesejahteraan perekonomian keseluruhan di wilayah provinsi Riau. Ketidakmampuan pertumbuhan ekonomi dalam mempengaruhi kesejahteraan cukup mendukung penelitian yang dilakukan Pratiwi \& Indrajaya (2019); Rosita \& Sita (2016).

\section{PENUTUP}

Penelitian ini bertujuan untuk mengetahui faktor-faktor yang mempengaruhi kesejahteraan masyarakat di Provinsi Riau. Tingkat kemiskinan, tingkat pengangguran, pengeluaran per kapita, pertumbuhan dapat menjelaskan terhadap kesejahteraan masyarakat sebesar 0.894630. Adapun hasilnya tingkat kemiskinan berpengaruh negatif dan pengeluaran perkapita berpengaruh positif terhadap kesejahteraan masyarakat, sedangkan tingkat pengangguran dan pertumbuhan tidak signifikan terhadap kesejahteraan masyarakat.

Untuk itu, pemerintah perlu melakukan skala prioritas dalam mengembangkan sektor ekonomi, terutama yang dapat menyerap tenaga kerja. Melakukan pemetaan dan pembenahan data masyarakat miskin agar dapat melakukan pembinaan dan pembrian bantuan yang tepat sasaran. Melihat kesaran masyarakat untuk berwirausaha tinggi, dibutuhkan intervensi pemerintah dalam mendukung terciptanya wirausaha yang berdaya saing. Hal ini perlu dilakukan karena wirausaha dipercaya memiliki peran dalam meningkatkan pembangunan ekonomi serta berdampak positif pada peningkatan kesejaheteraan.

\section{REFERENSI}

Adisasmita, R. (2013). Teori-Teori Pembangunan Ekonomi, Pertumbuhan Ekonomi dan Pertumbuhan wilayah. Yogyakarta: Graha Ilmu.

Al-Nasser, A. D., \& Hallaq, S. S. Al. (2019). Impact of human poverty on the human development index in jordan within the period 2003-2016. International Journal of Business and Society, 20(2), 552-562.

https://www.researchgate.net/publicati on/335715844

Amare, M., Asfaw, S., \& Shiferaw, B. (2012). Welfare impacts of maizepigeonpea intensification in Tanzania. Agricultural Economics, 43(1), 27-43. https://doi.org/10.1111/j.15740862.2011.00563.x

Arifin, Z., Maipita, I., \& Hutasuhut, S. (2020). the Effect of Capital Expenditure and Economic Growth on the Human Development Index of the District City in North Sumatera. Advances in Social Sciences Research Journal, 7(1), 585-594. https://doi.org/10.14738/assrj.71.7741

Ariza, A. (2016). Pengaruh Pertumbuhan Ekonomi Dan Belanja Modal Terhadap Indeks Pembangunan Manusia (Ipm) Dalam Perspektif Islam. Al-Maslahah Jurnal Ilmu Syariah, 12(1), 1-21. https://doi.org/10.24260/almaslahah.v1 $2 \mathrm{i} 1.348$

Badrudin, R., \& Kuncorojati, I. (2017). the Effect of District Own-Source Revenue and Balance Funds on Public Welfare By Capital Expenditure and Economic Growth As an Intervening Variable in Special District of Yogyakarta. Jurnal 
Manajemen Dan Kewirausahaan, 19(1), 54-59. https://doi.org/10.9744/jmk.19.1.54-59

BPK. (2008). Peraturan Pemerintah Republik Indonesia. https://peraturan.bpk.go.id/Home/Detai 1s/4820

BPS. (2018). Badan Pusat Statistik. https://www.bps.go.id/

Chalid, N., \& Yusuf, Y. (2014). Pengaruh Tingkat Kemiskinan dan Tingkat Pengangguran, Upah Minimun Kabupaten/Kota Dan Laju Pertumbuhan Ekonomi Terhadap Indeks Pembangunan Manusia di Provinsi Riau. Jurnal Ekonomi, 22(2), 1-12.

http://ejournal.unri.ac.id/index.php/JE/ article/viewFile/2592/2547\%0A

Churchill, S. A. (2020). Moving from the Millennium to the Sustainable Development Goals. In Moving from the Millennium to the Sustainable Development Goals. Palgrave Macmillan. https://doi.org/10.1007/978-981-151556-9

Darsana, A. G. K. P. \& I. B. (2016). Pengaruh Kemiskinan Dan Investasi Terhadap Pertumbuhan Ekonomi Dan Kesejahteraan Masyarakat. E-Jurnal EP Unud, 8 [6]: 1300-1330, 13001330.

Gomanee, K., Morrissey, O., Mosley, P., \& Verschoor, A. (2003). AID , Pro-Poor Expenditure And Welfare. World, 124.

Gujarati, D. N., Porter, D. C., \& Mardanugraha, E. (2013). Dasar-dasar Ekonometrika, buku 1 (5th ed.). Jakarta: Salemba Empat.

Kartasasmita, G. (1996). Pembangunan untuk rakyat: memadukan pertumbuhan dan pemerataan. Economic Development--Indonesia; Economic Policy; Economic Conditions-1945.

Maluccio, J., Haddad, L., \& May, J. (2000). Social capital and household welfare in South Africa, 1993-98. Journal of Development Studies, 36(6), 54-81. https://doi.org/10.1080/002203800084
22654

Mankiw, N. G. (2010). Macroeconomics (7th ed.). New York: Worth Publishers.

Mu'arifah, L. (2016). Tingkat Kesejahteraan Di Provinsi Daerah.

Nurarif. (2013). Analisis Pengaruh Produk Domestik Regional Bruto (PDRB) Terhadap Tingkat Kesejahteraan Masyarakat Kabupaten Way Kanan Tahun 2010-2015 Perspektif Ekonomi Islam. Journal of Chemical Information and Modeling, 53(9), 1689-1699.

https://doi.org/10.1017/CBO97811074 15324.004

Ojima, D. (2019). Unemployment and Economic Development In Nigeria ( 1980-2017 ). Advances in Social Sciences Research Journal -, 6(1), 110-121.

https://doi.org/doi.org/10.14738/assrj.6 1.5827

Paul, K. N., Hamdiyah, A., \& Samuel, A. D. (2014). Food expenditure and household welfare in Ghana. African Journal of Food Science, 8(3), 164175.

https://doi.org/10.5897/ajfs2013.1120

Pratiwi, N. P. A., \& Indrajaya, I. G. B. (2019). Pengaruh Pertumbuhan Ekonomi dan Pengeluaran Pemerintah Terhadap penyerapan Tenaga Kerja Serta Kesejahteraan Masyarakat di Provinsi Bali. Fakultas Ekonomi Dan Bisnis Universitas Udayana, 220-233.

Reyes, G. E., \& Useche, A. J. (2019). Competitiveness, economic growth and human development in Latin American and Caribbean countries 2006-2015: A performance and correlation analysis. Competitiveness Review, 29(2), 139159. https://doi.org/10.1108/CR-112017-0085

Rosita, P., \& Sita, A. (2016). Pengaruh Belanja Modal Terhadap Pertumbuhan Ekonomi Dan Kesejahteraan Masyarakat Di Pulau Kalimantan. STIE YKPN Yogyakarta, 2(2), 33-50. https://doi.org/10.26486/jramb.v2i2.28 4

Sholihah, F., \& Kustanto, M. (2017). Pengaruh Pertumbuhan Ekonomi dan 
Kesenjangan Pendapatan terhadap

Kesejahteraan Masyarakat Kabupaten

Sidoarjo. Seminar Nasional \& Call For

Paper, FEB Unikama "Peningkatan

Ketahanan Ekonomi Nasional Dalam

Rangka Menghadapi Persaingan

Global"Malang, 94-105.

Suganda, A. (2012). Pengaruh Pendapatan Asli Daerah dan Tingkat Pengangguran Terhadap Kesejahteraan Masyarakat Melalui Pertumbuhan Ekonomi. Ekonomi Dan Bisnis Universitas Tanjungpura, 91(5), 1-58.

Sugiyono. (2017). Metode Penelitian Bisnis.

Pendekatan Kuantitatif, Kualitatif,

Kombinasi dan $R$ \& $D$ (3rd ed.). Bandung: Alfabeta.

Sukirno, S. (2013). Teori Pengantar Makroekonomi (3rd ed.). Jakarta: Rajawali Pers.

Suryawati. (2003). Teori Ekonomi Mikro. Yogyakarta:UPP, AMP YKPNA.

Todaro, M. P., \& C. Smith, S. (2013). Pembangunan Ekonomi (11th ed.). Jakarta: Erlangga.

\section{BIODATA PENULIS}

Wiwin Indrayanti, merupakan mahasiswa tingkat akhir di jurusan ilmu ekonomi dan studi pembangunan Universitas Diponegoro. Saat ini penelitiannya fokus di bidang ekonomi dan publikekonomi pembangunan. 